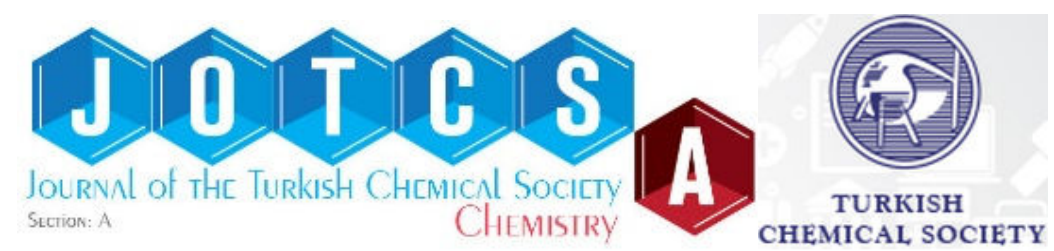

\title{
DNA- Binding, Biological Activities, and Chemical Composition of Wild Growing Epilobium angustifolium L. Extracts from Canakkale, Turkey
}

\author{
Aysema SAYIK ${ }^{1}$, Ayse Serguzel YUSUFOGLU ${ }^{1 *}$, Leyla ACIK ${ }^{2}$, Gulen TURKER ${ }^{3}$, Betul AYDIN ${ }^{2}$, \\ Leyla ARSLAN ${ }^{2}$ \\ ${ }^{1}$ Istanbul University, Chemistry Department, Organic Chemistry Division, Istanbul/Turkey \\ 2 Gazi University, Science Faculty, Biology Department, Molecular Biology and Genetics \\ Division Ankara/Turkey \\ ${ }^{3}$ Canakkale Onsekiz Mart University, Scientific and Technological Application Center, \\ Canakkale/Turkey
}

\begin{abstract}
The usage of Epilobium angustifolium L. in folk medicine against prostate and dermal diseases encouraged us to investigate pBR322 DNA-binding ability, biological activities and chemical composition of wild growing Epilobium angustifolium L.'s methanolic, ethanolic and aqueous extracts from Canakkale, Turkey. DNA-binding activity was studied by agarose gel electrophoresis and chemical composition via GC, GC-MS, HPLC, LC-MS, ICP-MS, and AAS. A detailed literature survey indicates no data on pBR322 plasmid DNA interaction of Epilobium species which is an important criterion for being a potential anticancer agent. Antibacterial and antifungal effects were tested against 11 bacteria and 3 fungi and compared with ampicillin, chloramphenicol, and ketoconazole by agar well diffusion techniques. Total phenolic content was found by Folin-Ciocalteu method, and antioxidant activity was obtained by DPPH and Fe(II)-FZ (ferric-ferrozine) methods. This plant is rich in flavonoids, hormones, fatty acids, and phenolic acids. $\mathrm{Si}, \mathrm{K}, \mathrm{Mg}, \mathrm{P}$, and $\mathrm{Mn}$ were the main inorganic elements. Epilobium angustifolium L. with its high DNA-binding activity and rich chemical composition can be an excellent potential anticancer, antimicrobial and antioxidant prodrug.
\end{abstract}

Keywords: DNA-Binding activity, pBR322 plasmid DNA-Binding, Epilobium angustifolium L. extracts, cancer therapeutic, chemical analysis.

Submitted: 07 June, 2017. Accepted: August 02, 2017.

Cite this: Sayık A, Serguzel Yusufoğlu A, Acık L, Turker G, Aydın B, Arslan L. DNA- Binding, Biological Activities, and Chemical Composition of Wild Growing Epilobium angustifolium L. Extracts from Canakkale, Turkey. JOTCSA. 2017 Jul;4(3):811-40.

DOI: $10.18596 /$ jotcsa.319789.

*Corresponding author. E-mail: ayseserg@istanbul.edu.tr. 


\section{INTRODUCTION}

The genus Epilobium is found all over the world and consists of nearly 250 species. Since both phytochemical content and biological activities show differences according to plant location, we studied the Turkish origin for its chemical composition and biological activities (1). Various species of Epilobium are used in folk medicine mainly for prostatic disease and any other health disorders and in cosmetic as skin anti-aging. Epilobium angustifolium $L$. has been found (2) being effective on prostaglandin biosynthesis and inducing edema. Anti-inflammatory effects of the plant have also been determined (3). Anti-diarrhoeic, anti-secretory, and anti-motility activities have been researched (4) for gastrointestinal treatment. Analgesic activity of Epilobium angustifolium L. has been investigated (5). Myricetin-3-O-beta-D-glucuronide has been isolated and determined (6) as an antiphlogistic principle and also examined (7) for its anti-inflammatory activities. A study (8) has displayed the activity of Epilobium angustifolium L. extract against the LNCaP in human hormone dependent prostate cancer cells. Epilobium angustifolium L. includes Oenothein B, and this component has been analyzed for its inhibition activity of 5-alphareductase and aromatase enzymes that raise benign prostatic hyperplasia, BPH (9). Oenothein $B$ is a dimeric ellagitannin and has also been proved to affect the NEP activity in prostatic cancer progression (10). According to Vitalone, Epilobium angustifolium L. and its Oenothein B were effective to inhibit DNA synthesis in the human prostate cell line. All these scientific researches show that the use of this herb is appropriate for prostate disease among the people. Obtained results caused the Community on Herbal Medicinal Products (12) to publish a directive of Epilobium angustifolium $L$. for the folk medicinal application against prostatic disease. Epilobium angustifolium $L$. is also the main source to obtain Oenothein B. Its patented medicaments can be used to heal skin disorder (13). An important component of the plant, "Oenothein B" showed (14) cytotoxic activity against human oral tumor cell lines. In other studies $(15,16)$ Oenothein $B$ had antitumor activity against sarcoma-180 in mice. According to the antimicrobial analysis by Rauha Petal (17), Epilobium angustifolium L. is one of the most active plants. In another study (18) about Epilobium species, Epilobium angustifolium L. showed antimicrobial activity inhibiting bacteria and fungi. Leaves and flowers of the plant were searched (19) in vitro for antimicrobial activity in the early stages of $\mathrm{BPH}$, and aqueous plant extract demonstrated antifungal activity (20). Total phenolics in plant extract were measured as GAE of antioxidant activity (21). Radical scavenging capacity (RSC) was investigated (22) by DPPH assay and total reducing power by FRAP (23). Immunomodulatory activity was examined in vivo and in vitro (24) relating to Oenothein B content. Epilobium angustifolium L. of Mongolian origin has been searched (25) for its free radical scavenging property. Antitumor activity of Oenothein B isolated from Epilobium angustifolium L. was studied (26) in vivo against MM2 ascites tumors and in vitro by treatment of macrophages from mice and humans. 
Epilobium angustifolium $L$. is also digestive as tea, vegetable, soup, and salad (27) and called as "Fire Weed" because of its occurring within the vegetation after forest fires (28).

This study has three aims; one of them is to investigate the general pBR322 plasmid DNA binding, antibacterial, antifungal and antioxidant activities of ethanolic and methanolic extracts of Epilobium angustifolium L. in order to use it as a potential anticancer, antimicrobial, antifungal and antioxidant prodrug. These biological activities of this plant were not investigated before in Turkey. According to the literature survey, there is no data about the general pBR322 plasmid DNA-binding effect of Epilobium angustifolium L. DNA-binding effect is one of the criteria for inhibition of cancer and usage as an anticancer agent (29). Cancer is the uncontrolled and abnormal growth of cell as a result of DNA damage $(30,31)$. DNA-binding agents with different functional groups are present in the composition of the anticancer drugs.

Secondly, it is aimed to analyze the chemical composition of this plant for flavonoids, steroid hormones, fatty acids, phenolic acids, and inorganic elements as bioactive substances which were not studied before in Turkey. Besides, DNA-binding ability and inorganic elements of Epilobium angustifolium $L$. were also not investigated in the literature.

The third aim is to establish a relationship between the chemical composition and all these mentioned biological activities.

\section{MATERIALS AND METHODS}

\section{Standards and Reagents}

Sigma HPLC grade methyl alcohol and ethyl alcohol were used for extraction. Merck HPLC purity grade hexane was used for extraction of fatty acid components. $37 \%$ Merck fuming $\mathrm{HCl}$ was used for hydrolyzation. Flavonoid standards were Sigma pure grade. [Quercetin, Myricetin, Hyperoside, Quercitrin, Quercetin glucoside, Kaempferol, Apigenin, Catechin, Cyanidin chloride, Delphinidin chloride, Isoquercetin, Kerocyanin chloride, Luteolin, Malvidin, Naringenin, pcoumaric acid, Pelargonidin, and Peonidin chloride]. Deionized water was obtained with Millipore (Ultrapure Milli-Q) Water Purification Systems. Plant materials and chemicals were weighed on Sartorius A200 Series scale. AcN, TFA, Formic acid, Ethyl acetate, chloroform, DMSO were also HPLC purity grade. Extra pure Merck silica gel 60 (0.063-0.200 mm) was used for column chromatography to fractionize the ethanolic and methanolic extracts. Petroleum ether was of Sigma pure grade. 


\section{Collection of E. angustifolium L. and Preparation of the Extracts}

The Epilobium angustifolium L. was collected at the flowering season from Canakkale, Turkey and identified by the Faculty of Pharmacy, Istanbul University. (Herbarium code number; ISTE 83909). The overground parts of Epilobium angustifolium L. from Canakkale, Turkey were washed with deionized water and dried for 5 to 7 days in the shade at room temperature. The dried parts were powdered finely. For the determination of all these activities, Epilobium angustifolium $L$. powder was extracted with both ethyl alcohol and methyl alcohol separately with the same procedure as follows. $10 \mathrm{~g}$ of the mixtures obtained from the aerial parts of the powdered plant leaves, flowers, stems, and seeds were extracted with $250 \mathrm{~mL}$ of ethyl alcohol and $250 \mathrm{~mL}$ of methyl alcohol separately by Soxhlet extraction method. The alcoholic extracts were filtered and evaporated to dryness under reduced pressure at $40{ }^{\circ} \mathrm{C}$ in a rotary evaporator. These crude extracts were stored at $-10^{\circ} \mathrm{C}$ until analyses. The residues were dissolved in DMSO and analyzed for the biological activities.

Aqueous extract for MS, GC - MS, LC-MS and HPLC Analysis

The aqueous extract sample; $10 \mathrm{~g}$ of the homogeneous content of stems, leaves, and seeds were prepared from the plants. This plant material was extracted with $250 \mathrm{~mL}$ of distilled water extracted for 3 hours by Soxhlet extraction method. The extract was filtered, evaporated to dryness under reduced pressure at $60^{\circ} \mathrm{C}$ in a rotary evaporator under vacuum until $30 \mathrm{~mL}$ thick residue was left. The residue was analyzed.

Ethanolic Extract for GC-MS and LC-MS Analysis

Stems, leaves, and seeds from the plant to contain a homogeneous mixture of about $10.22 \mathrm{~g}$ of dried Fire Weed (Epilobium angustifolium L. ) were taken in ordinary filter paper for making a capsule in the Soxhlet apparatus with $330.95 \mathrm{~g}$ of ethyl alcohol for extraction. The alcoholic extract was filtered and evaporated to dryness under reduced pressure at $40^{\circ} \mathrm{C}$ in a rotary evaporator.

Methanolic Extract for GC-MS Analysis and HPLC

The methanolic extract prepared by Soxhlet extraction method was evaporated under reduced pressure at $40^{\circ} \mathrm{C}$ to separate the crude extract from methanol. After removing the solvent, the gained crude extract was fractionated by column chromatography with various chloroformmethanol mixtures on silica gel $60(0.063-0.200 \mathrm{~mm})$. All acquired fractions were analyzed by GC-MS. This analysis was especially performed to determine the steroid structural hormonal components. Fortunately, many different functional substances were observed besides the 
hormones. Methanolic extract's GC-MS analysis exhibited much more compounds than both ethanolic extract and aqueous extract.

\section{Hydrolysate Samples}

Epilobium angustifolium L. plants' aqueous extract, ethanolic extract, and dry plant were hydrolyzed according to same hydrolyzation way, and all these obtained hydrolysates were analyzed by the LC-MS method. In the hydrolysis method(35); $25 \mathrm{~mL}$ of aqueous extract, $25 \mathrm{~mL}$ ethanolic extract, and $25 \mathrm{~g}$ of the dry plant were respectively hydrolyzed with same time for each hydrolysis. $25 \mathrm{~mL}$ of methanol ( $1 \%$ by volume $\mathrm{HCl}$ ) comprises was added over the indicated amounts of samples. $5 \mathrm{~mL}$ of $1.2 \mathrm{M} \mathrm{HCl}$ was added to each mixture, and the total mixtures were refluxed at $90^{\circ} \mathrm{C}$ for 2 hours. Then the refluxed liquids were cooled to room temperature and allowed to wait for 3 minutes to provide the removal of oxygen by using a sonic bath.

\section{Sample Preparation for Plant's Fatty Acid Composition}

A homogeneous $10 \mathrm{~g}$ mixture of plant stems, leaves and flowers was used to put in a capsule for extraction. This mixture was extracted by Soxhlet apparatus with $250 \mathrm{~mL}$ of hexane for 4 hours. The obtained extract was evaporated at $40^{\circ} \mathrm{C}$ under vacuum until about $10 \mathrm{~mL}$ of the thick residue was gained. $0.3 \mathrm{~g}$ of the residue was allowed to wait with $18.5 \mathrm{~mL}$ boron trifluoridemethanol complex at $50^{\circ} \mathrm{C}$ water bath for 10 minutes to yield the methyl esters of the possible fatty acids. The resulting material was shaken with petroleum ether; it was made neutral by washing with distilled water for two times. Petroleum ether phase taken, incubated with 1 spatula of sodium sulfate for 15 minutes. This prepared sample was analyzed by GC.

Inorganic Elements Analysis of the Plant

Dry sample was prepared as follows; the aerial parts of the plant with a mixture of the stem, seeds, flowers, and leaves were thoroughly pulverized in a mortar with a pestle. The previously prepared aqueous extract was also analyzed for inorganic elements.

\section{DNA-Binding Studies and Biological Activities}

\section{Studies of Interaction with pBR322 plasmid DNA}

The interaction of compounds with pBR322 plasmid DNA was investigated by agarose gel electrophoresis. The extract incubated with supercoiled plasmid pBR322 DNA in the dark at 37 ${ }^{\circ} \mathrm{C}$ for $24 \mathrm{~h}$. The aliquots of the DNA/extract mixtures were mixed with the loading buffer $(0.1 \%$ 
bromophenol blue, $0.1 \%$ sucrose) and loaded onto the $1 \%$ agarose gel. Electrophoresis was carried out in TAE buffer ( $0.05 \mathrm{M}$ Tris base, $0.05 \mathrm{M}$ glacial acetic acid and $1 \mathrm{mM}$ EDTA, $\mathrm{pH}=8.0$ ) for $3 \mathrm{~h}$ at $70 \mathrm{~V}$. Afterwards, the gel was stained with ethidium bromide $(0.5 \mu \mathrm{g} / \mathrm{mL})$, visualized under UV light using a transilluminator (BioDoc Analyzer, Biometra) and the image was captured with a video camera as a TIFF file. The experiments were repeated three times.

\section{Antimicrobial Activity Analysis}

The antimicrobial activities of plant extracts were assessed against bacterial strains; Bacillus cereus, NRRL B-3711, Bacillus subtilis ATCC 6633, Staphylococcus aureus ATCC 25923, Enterococcus faecalis ATCC 29212, Enterococcus hirae ATCC 9790, Escherichia coli ATCC 35218, Escherichia coli ATCC 25922, Pseudomonas aeruginosa ATCC 27853, Klebsiella pneumaniae ATCC 13883, Salmonella typhimurium ATCC 14028, Proteus vulgaris RSKK 96029 and fungal strains Candida albicans ATCC 10231, Candida krusei ATCC 6258, Candida tropicalis Y-12968 by using agar well diffusion method. For comparison; ampicillin, chloramphenicol (antibacterial) and ketoconazole (antifungal) were used as the standard antibiotics. Test strains were incubated on sabouraud dextrose agar plates at $30^{\circ} \mathrm{C}$ for $48 \mathrm{~h}$ for fungi. After incubation, fungal suspensions were adjusted to a turbidity of 0.5 McFarland. Sabouraud dextrose agar (for fungal strains) mixed with $1 \%$ culture suspension and poured into the plates. Wells with a $6.0 \mathrm{~mm}$ diameter were prepared, and the solution of the $100 \mathrm{mg} / \mathrm{mL}$ plant extract ( $50 \mu \mathrm{L}$ ) was added to the well. After incubation, the diameter of the inhibition zone was measured in millimeters. The minimum inhibitory concentration (MIC) and minimum bactericidal concentration (MBC) values of the extracts which were shown antimicrobial activity were determined by the broth microdilution method. MIC is the lowest concentration of an antimicrobial that will inhibit the visible growth of a microorganism after incubation. $M B C$ is the lowest concentration an antimicrobial agent required to kill a particular bacteria or fungi.

\section{Free Radical Scavenging Activity Using DPPH• radical}

The scavenging activity of the stable 1,1-diphenyl-2-picrylhydrazyl (DPPH•) free radical was determined by the method described by Braca (32) with some modifications. Samples (1 $\mathrm{mL}$ ) were mixed with $1 \mathrm{~mL}$ of DPPH in methanol $(0.04 \mathrm{mg} / \mathrm{mL})$, incubated $30 \mathrm{~min}$ at room temperature, and the absorbance was measured at $517 \mathrm{~nm}$. Methanol and butylated hydroxytoluene (BHT) was used as negative control and as the standard of the assay, respectively. The inhibition activity $(\%)$ of DPPH radicals was calculated as $\left[\left(A_{0}-A_{1}\right) / A_{0}\right] \times 100$, where $A_{0}$ was the absorbance of the negative control, and $A_{1}$ was the absorbance of the extracts. The concentration of sample required to reduce $50 \%$ of DPPH radicals (IC50) was calculated from linear regression analysis. 


\section{Estimation of Total Phenolics}

The total phenolic content was determined according to the Folin-Ciocalteau method described by Siddhuraju and Becker (33) with some modifications. For the assay, aliquots (100 $\mu \mathrm{L})$ of extracts were taken in test tubes. Then $0.2 \mathrm{~mL}$ of Folin-Ciocalteau phenol reagent (1:1 with water) was added to each tube and incubated for $3 \mathrm{~min}$. Then $1 \mathrm{~mL}$ of sodium carbonate solution $(2 \%)$ were added sequentially to each tube. Soon after vortexing the reaction mixture, the test tubes were placed in the dark for $1 \mathrm{~h}$. The absorbance was recorded at $760 \mathrm{~nm}$ against the reagent blank. The analysis was performed in triplicate, and the results were expressed as the gallic acid equivalents.

\section{Metal Chelating Activity}

The extracts $(1.85 \mathrm{~mL})$ were added to a solution of $2 \mathrm{mM} \mathrm{FeCl} 2(0.05 \mathrm{~mL})$ and incubated for 5 $\min$. The reaction was initiated by the addition of $5 \mathrm{mM}$ ferrozine $(0.1 \mathrm{~mL})$, and the mixture was shaken vigorously and left standing at room temperature for $10 \mathrm{~min}$ Absorbance of the solution was then measured spectrophotometrically at $562 \mathrm{~nm}$. The solvent of the extracts was used as negative control of the assay. The chelating activity (\%) of the extracts was calculated as $\left[\left(A_{0}-A_{1}\right) / A_{0}\right] \times 100$, where $A_{0}$ was the absorbance of the negative control, and $A_{1}$ was the absorbance of the extracts. The concentration of sample required to reduce $50 \%$ of iron (II) ions (IC50) was calculated from linear regression analysis(34).

\section{Chemical Analysis' Instrumental Conditions; MS, GC-MS, LC-MS, HPLC, GC, ICP-MS and AAS were used.}

MS Analysis Conditions

MS spectra were recorded with Thermo MS analyzer. Source voltage was set to $1920 \mathrm{~V}$, and the source current was $6.10 \mathrm{kV}$. The vaporizer temperature was $450.10{ }^{\circ} \mathrm{C}$. The capillary temperature and capillary voltage were set to $251.60^{\circ} \mathrm{C}$ and $-46.99 \mathrm{~V}$, respectively. Sheath gas was at a flow rate of $59.42 \mathrm{~mL} / \mathrm{min}$. Sweep gas flow rate was $19.66 \mathrm{~mL} / \mathrm{min}$. Tube lens voltage was $-50.00 \mathrm{~V}$. Analysis was carried out with APCI detector. The results were determined according to molecular weights.

\section{GC-MS Analysis Conditions}

Methanolic, ethanolic, and aqueous extracts' analyses were performed on a Shimadzu GC 2010 instrument equipped with QP 2010 Plus mass spectrometer. A nonpolar fused silica capillary column TRB 5MS and a polar column ZB50 were used for the separations. The carrier gas was helium with constant flow rate as $1 \mathrm{~mL} / \mathrm{min}$. Injection volume was $1 \mu \mathrm{L}$ with the splitless mode. EI was used as the ion source, and the ion source temperature was $270^{\circ} \mathrm{C}$. The mass analyzer was set to scan from 5 to $1050(\mathrm{~m} / \mathrm{z})$. The temperature was held at $50^{\circ} \mathrm{C}$ for 1 minute. It rose 
at a rate of $2{ }^{\circ} \mathrm{C} / \mathrm{min}$ to $200^{\circ} \mathrm{C}$ and held at $200{ }^{\circ} \mathrm{C}$ for $20 \mathrm{~min}$. Secondly, it rose to $280{ }^{\circ} \mathrm{C}$ at an increasing rate of $5{ }^{\circ} \mathrm{C} / \mathrm{min}$ and kept for $5 \mathrm{~min}$. The identifications of the components were exhibited by matching their mass spectra from the Wiley library data provided by the software of the GC-MS system.

\section{LC-MS Analysis Conditions}

LC/PDA -MS analysis' instrument was Thermo associated with Hypersyl Gold column (150 mm x 4,6 $\mathrm{mm} \times 5 \mu \mathrm{m})$. ESI (-) and (+) techniques were used for analysis. Photo diode array was used for detection for two wavelengths as $250 \mathrm{~nm}$ and $350 \mathrm{~nm}$. Elution was carried out with solvent A: formic acid; AcN (5: $1000 \mathrm{~V} / \mathrm{V}$ ) and solvent B: formic acid; deionized water (5: $1000 \mathrm{~V} / \mathrm{V}$ ). Used standards and their retention times were given in Table 11. Elution program for Solvent A/Solvent B was as; 0-8 min: 18/82, 8-18 min: 8-53/82-47, 18-18(1 min): 53-97/47-3, 18.119 min: $97 / 3,19-29 \min : 97 / 3,29-30 \mathrm{~min}: 97-18 / 3-82,30-40 \mathrm{~min}: 18 / 82$. The flow rate was $1 \mathrm{~mL} / \mathrm{min}$. Analysis results were determined according to standards. Flavonoid structures of different samples were analyzed by LC-MS and decided according to 4 standards, namely Hyperoside, Isoquercetin, Quercitrin, Quercetin.

\section{HPLC Analysis Conditions}

Chromatography was executed by a Shimadzu LC 20AT liquid chromatograph connected to DGU 20A5 prominence degasser and SPD M20A photodiode array detector (PDA). Other constituents were as SIL 20AC autosampler and CTO 10AS UP column oven. Separation was carried out on an octadecyl silyl C18 column streamed with mixtures of $0.1 \%$ TFA (TFA solution with deionized water: solvent $A$; 0.1 TFA: 99.9 deionized water) and acetonitrile:deionized water (8:2) containing $0.1 \%$ TFA (solvent $B$ ) at a flow rate of $0.5 \mathrm{~mL} / \mathrm{min}$. The analytic process was step gradient from $90: 10(A: B)$ to $80: 20$ in 15 min subsequently from $80: 20$ to $60: 40$ in 10 min and next from 60:40 to 40:60 in $10 \mathrm{~min}$ from 40:60 to 30:70 in 10 min Injection volume was $10 \mu \mathrm{L}$ for all analysis. Detection was achieved with five wavelengths as 220, 250, 350, 380, and 540 $\mathrm{nm}$. Firstly, standards were dissolved in methanol then prepared samples were analyzed at these wavelengths. Flavonoids of samples were determined according to standards' corresponding retention times and UV spectra. Identifications were according to 21 standards as; Apigenin, Catechin, Cyanidin chloride, Cyanidin glucoside, Cyanine, Delphinidin chloride, Hyperoside, Isoquercetin, Kaempferol, Kerocyanin chloride, Luteolin, Malvidin, Myricetin, Naringenin, pCoumaric acid, Pelargonidin, Peonidin chloride, Quercetin, Quercetin galactoside, Quercetin glucoside, Quercetin rhamnoside. 


\section{Fatty Acids' GC Analysis Conditions}

The instrument was Agilent consisting of Inlet A: PSSI and Inlet B: CAP. Beginning temperature was $100^{\circ} \mathrm{C}$ for $1 \mathrm{~min}$. Increasing degree was $10^{\circ} \mathrm{C} / \mathrm{min}$. It was held $38 \mathrm{~min}$ at $230^{\circ} \mathrm{C}$. Total run time was 82.33 min Detector B was FID. The results were evaluated according to standards.

Inorganic Elements Analysis Conditions

Both dry pulverized plant material and aqueous extract sample were analyzed on ThermoElemental ICP-MS-X Series according to qualitative and semi quantitative scanning method. Dry pulverized plant material was also analyzed on Analyst 200 Flame, Analyst 600 Graphite-Furnace and hydride systems (Perkin Elmer) according to AAS (Atomic Absorption Spectrophotometer) method as qualitative and quantitative.

\section{RESULTS AND DISCUSSION}

\section{DNA-binding Studies and Biological Activities.}

"Number 1 " is methanolic extract, and "Number 2 " is ethanolic extract for all DNA-binding, antioxidant, antimicrobial and antifungal studies.

\section{Studies of Interaction with plasmid DNA}

Gel electrophoresis of control and treated plasmid DNA gave two bands corresponding to supercoiled Form I and singly nicked Form II DNA (36). When it was electrophoresed after its interaction with plant extract, there is a significant change in intensity and mobility of form I and form II DNA (Figure 1). The result showed that there was no Form I and Form II bands at two high concentrations of the extract (Lanes 1 and 2) possibly was indicative of DNA damage rather than any change in DNA conformation. Although the change was less dramatic at the three other concentrations, the intensity of form II DNA increased and linear form III DNA indicated DNA conformational changes. 


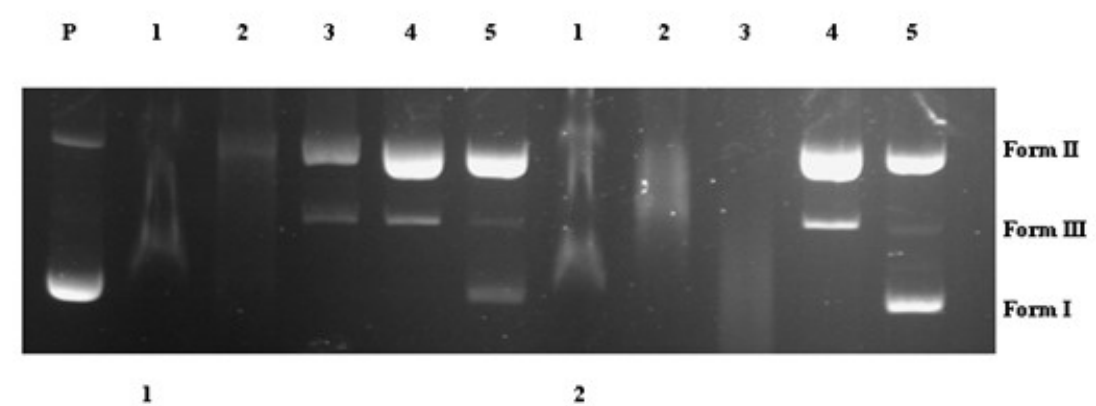

Figure 1. The effect of the plant extracts on plasmid DNA. Gel electrophoretic mobility of plasmid DNA when incubated with various concentrations of extracts 1-2. Concentrations (in $\mathrm{mg} / \mathrm{mL}$ ) as follows: lane $P$, untreated plasmid DNA; lane 1, 100; lane 2, 50; lane 3, 25; lane 4, 12,$5 ;$ lane $5,6.25$.

\section{HindIII restriction enzyme digestion}

In order to learn information if extract bound to DNA, the DNA-extract incubation mixture was followed by HindIII and BamHI restriction. Figure 2 gave the electrophoretogram applying to the interaction of plasmid DNA with plant extract for a period of 24 hours followed by HindIII and BamHI restriction for a further 1-hour incubation respectively. When plasmid DNA was restricted with the enzymes, only one band corresponding to linear form III band was observed whereas in the treated DNA two bands form II and form III bands were observed. The results indicated that the extracts bound to DNA and inhibited digestion of DNA by the enzymes.

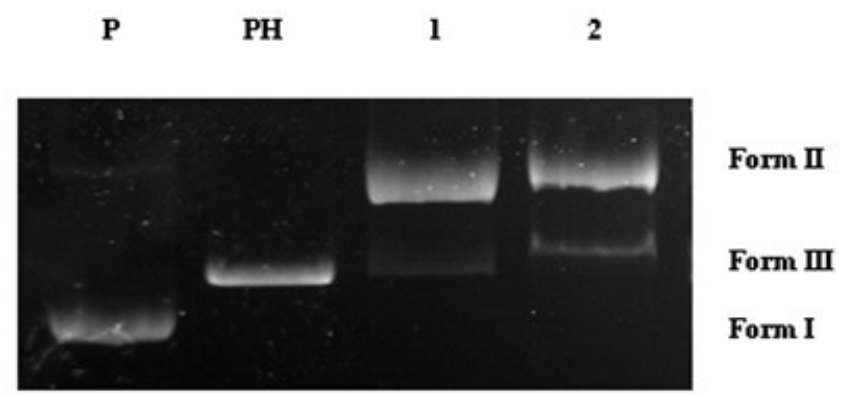

Figure 2. Electrophoretograms for the HindIII digested mixtures of plasmid DNA after their treatment with extracts 1-2. Untreated plasmid DNA was applied to lane P; lane PH applies plasmid DNA digested with HindIII. Lanes 1-2 applies to plasmid DNA interacted with the extracts 1-2 followed by their digestion with HindIII. As a result, the extracts were found to be very active against DNA and bind to DNA.

\section{The Antimicrobial Activity}

The antimicrobial activity of the extracts was determined against bacterial and fungal test strains.

The minimum inhibitory concentration (MIC) and minimum bactericidal concentration (MBC) values of the extracts were given in Table 1 and Table 2, respectively. All of the extracts showed 
their inhibitory and bactericidal activity in lower concentrations in comparison with standard antibiotics ampicillin and chloramphenicol. Whereas MIC values of the extracts were 1.56-6.25 $\mathrm{mg} / \mathrm{mL}$ and $\mathrm{MBC}$ values were $1.56-12.5 \mathrm{mg} / \mathrm{mL}$, MIC and MBC values of the standard antibiotics are $>125-3.91 \mathrm{mg} / \mathrm{mL}$. According to these results, plant extracts 1 and 2 were as effective antimicrobial agents as ampicillin and chloramphenicol. Otherwise, the plant extracts which were used in this study exhibited no antifungal activity against candidal strains (Table 3 ).

Table 1. Minimum inhibitory concentrations of the extracts against test strains (MIC values are reported in $\mathrm{mg} / \mathrm{mL}$ )

\begin{tabular}{|c|c|c|c|c|}
\hline \multirow[b]{2}{*}{ Test microorganisms } & \multicolumn{2}{|l|}{ Extracts } & \multicolumn{2}{|c|}{$\begin{array}{l}\text { Positive } \\
\text { control }\end{array}$} \\
\hline & $\begin{array}{l}\text { 1(Met. } \\
\text { extract) }\end{array}$ & $\begin{array}{l}\text { 2(Eth. } \\
\text { Extract) }\end{array}$ & Amp & C \\
\hline B. cereus NRRL B-3711 & 1.56 & 1.56 & 31.25 & 125 \\
\hline B. subtilis ATCC 6633 & 1.56 & 1.56 & 62.5 & 3.91 \\
\hline S. aureus ATCC 25923 & 6.25 & 3.13 & 62.5 & 125 \\
\hline P. vulgaris RSKK 96029 & - & 3.13 & $>125$ & 125 \\
\hline
\end{tabular}

Amp: Ampicillin, C: Chloramphenicol are standards for antibacterial activity.

Table 2. Minimum bactericidal concentrations of the extracts against test strains (MBC values are reported in $\mathrm{mg} / \mathrm{mL}$ )

\begin{tabular}{lllll}
\hline & \multicolumn{2}{l}{ Extracts } & \multicolumn{2}{l}{$\begin{array}{l}\text { Positive } \\
\text { control }\end{array}$} \\
\cline { 2 - 5 } Test microorganisms & $\begin{array}{l}\text { 1(Met. } \\
\text { extract) }\end{array}$ & $\begin{array}{l}\text { 2(Eth. } \\
\text { Extract) }\end{array}$ & Amp & C \\
& 1.56 & 1.56 & $>125$ & $>125$ \\
\hline \hline B. cereus NRRL B-3711 & 1.56 & 1.56 & 62.5 & 3.91 \\
B. subtilis ATCC 6633 & 12.5 & 6.25 & 62.5 & $>125$ \\
S. aureus ATCC 25923 & - & 6.25 & $>125$ & $>125$ \\
P. vulgaris RSKK 96029 & & & \\
\hline \hline
\end{tabular}

Amp: Ampicillin, C: Chloramphenicol are standards for antibacterial activity.

\section{Antioxidant Activity}

Free radical scavenging activities of the plant extracts were determined by DPPH method. IC50 values of methanolic and ethanolic extracts were $9.69 \pm 0.22$ and $16.06 \pm 0.54$, respectively (Table 4). Total phenolic contents of methanolic and ethanolic extracts were found as $369.85 \pm$ 1.96 and $236.13 \pm 0.21$ respectively (Table 5 ). Metal chelating activities of the plant extracts were $3.21 \pm 0.21$ and $7.79 \pm 0.24$ (Table 6 ). Free radical scavenging activity and metal chelating activity of the ethanolic extract was more effective than methanolic extract's while the total phenolic content of the methanolic extract was higher than ethanolic extract. 
Sayık, Yusufoğlu, Acık et al., JOTCSA. 2017; 4(3): 811-840.

Table 3. Antifungal activity of the compounds expressed as inhibition zones ( $\mathrm{mm})$.

\begin{tabular}{|c|c|c|}
\hline & Extracts & Positive control \\
\hline $\begin{array}{l}\text { Test microorganisms for } \\
\text { fungi }\end{array}$ & $\begin{array}{lrlr}1 & \text { (Met. } & 2 & \text { (Eth. } \\
\text { extract) } & \text { Extract) }\end{array}$ & Amp \\
\hline
\end{tabular}

$\begin{array}{llllll}\text { C. albicans ATCC } 10231 & - & - & \text { NS } & \text { NS } & 11 \pm 1 \\ \text { C. krusei ATCC } 6258 & - & - & \text { NS } & \text { NS } & 18 \pm 1 \\ \text { C. tropicalis Y-12968 } & - & - & \text { NS } & \text { NS } & 34 \pm 2\end{array}$

Amp: Ampicillin, C: Chloramphenicol are standards for antibacterial activity. Keto: Ketoconazole is standard for antifungal activity. (NS: Not studied)

Table 4. Free radical scavenging activities of the plant extracts expressed as IC50.

\begin{tabular}{ll}
\hline Sample & $\mathrm{IC50}(\mu \mathrm{g} / \mathrm{mL})$ \\
\hline Methanolic extract & $9.69 \pm 0.22$ \\
Ethanolic extract & $16.06 \pm 0.54$ \\
BHT $^{1}$ & $96.47 \pm 0.54$ \\
\hline
\end{tabular}

${ }^{1} \mathrm{BHT}$ : Butylated hydroxytoluene as positive control

Table 5. Total phenolic content of the plant extracts as mg gallic acid equivalent.

\begin{tabular}{ll}
\hline Sample & $\begin{array}{l}\text { Total phenolic content } \\
(\mathrm{mg} \mathrm{GAE} / \mathrm{g} \text { extract })\end{array}$ \\
\hline Methanolic extract & $369.85 \pm 1.96$ \\
Ethanolic extract & $236.13 \pm 0.21$ \\
\hline
\end{tabular}

Table 6. Metal chelating activities of the plant extracts expressed as IC50.

\begin{tabular}{ll}
\hline Sample & $\mathrm{IC}_{50}(\mu \mathrm{g} / \mathrm{mL})$ \\
\hline Methanolic extract & $3.21 \pm 0.21$ \\
Ethanolic extract & $7.79 \pm 0.24$ \\
\hline
\end{tabular}

Antioxidants are expected to have antimicrobial activity $(37,38,39)$. This relation is valid for this study. Both data as antioxidant capacity-total phenolic content and antimicrobial activity levels are in consistency as being an active purposive agent. In this study; metal chelating activity (ferric-ferrozine), total phenolic content (as gallic acid equivalent with Folin- Ciocalteu method) and free radical scavenging activity (DPPH) was used in combined manner to determine 
antioxidant activity. High amounts of total phenolic contents are in correlated with strong DPPH and Fe (II)-FZ (ferric-ferrozine) assays.

\section{Chemical Composition Analysis}

GC-MS Analysis of Ethanolic Extract

Analysis of Ethanolic Extract on Polar Column

Ethyl alcohol extract contains; octadecanol and hexadecanol as long chain alcohols. Farnesol, 1Iodoundecane, and 1,2-Dimethyl-benzene ( $p$ - or $0^{-}$) are some of the observed components (Table 7).

Table 7. Ethanolic extract's compounds on the polar column.

\begin{tabular}{lll}
\hline $\begin{array}{l}\text { Retention } \\
\text { times }\end{array}$ & Compound & $\%$ \\
\hline 3.35 & Tricyclo [4.1.0.0 (2,7) ]hept-3-en & 5.64 \\
3.40 & Paraffin type compound & 5.22 \\
5.52 & 1,2-Dimethyl-benzene (p- or o- ) & 5.28 \\
6.05 & 4-Hydroxy-4-methyl-2-pentanone & 2.02 \\
6.27 & Decane (paraffin type ) & 1.47 \\
10.12 & Dodecane (paraffin type) & 5.52 \\
31.64 & Hexanoic acid & 0.82 \\
38.72 & Octandioic acid, dimethyl ester & 4.66 \\
51.15 & 1-Iodoundecane & 4.73 \\
59.09 & 2,3- Dihydrofuran & 0.20 \\
65.59 & Octadecanol \\
& Hexadecanol \\
67.45 & (-) - Loliolide \\
& 2- Isononeal & 4.24 \\
65.81 & Dodecanoic acid, methyl ester & 1.89 \\
75.67 & Di- (2-ethylhexyl) phthalate & \\
101.04 & Palmitic acid glycerol ester & 0.33 \\
& 2-Hydroxyhexadecanoic acid ethyl ester & 1.58 \\
102.90 & 1,2-Benzenedicarboxyilic acid, bis(2-ethylhexyl & 0.16 \\
& )ester & \\
107.50 & Farnesol (sesquiterpene type ) & 0.42 \\
\hline
\end{tabular}


Sayık, Yusufoğlu, Acık et al., JOTCSA. 2017; 4(3): 811-840.

Analysis of Ethanolic Extract on Nonpolar Column

Table 8. Ethanolic extract's compounds on the nonpolar column.

\begin{tabular}{lll}
\hline $\begin{array}{l}\text { Retention } \\
\text { times }\end{array}$ & Compound & $\%$ \\
18.643 & Heptadecanoic acid, ethyl ester & 2.38 \\
16.913 & Hexadecanoic acid, ethyl ester & 15.07 \\
16.560 & Hexadecanoic acid & 17.93 \\
15.683 & Phthalic acid, butyl ester & 1.15 \\
15.356 & 2-Pentadecanone & 2.74 \\
14.343 & Hexadecanoic acid & 1.13 \\
12.366 & 1-Tetradecanol & 3.26 \\
10.433 & L(+)-Glutamic acid hydrochloride & 25.34 \\
9.902 & 1,3,5-Triazine & 0.66 \\
8.846 & Trans-2-methyl-3-isopropyl aziridine & 0.91 \\
7.386 & 2-Furancarboxaldehyde & 11.87 \\
6.250 & 4H-Pyran-4-one,2,3-dihydro-3,5-dihydroxy-6-methyl & 4.37 \\
\hline 15.202 & 5-methyloctane & 2.09
\end{tabular}

Hexadecanoic acid, ethyl ester and Hexadecanoic acid, 1-Tetradecanol were important fatty acid and derivatives in ethanolic extract of the plant. The $L(+)$-Glutaminic acid hydrochloride is an important medicinal and nutritional compound. 2-Furancarboxaldehyde is a valuable chemical feedstock (Table 8).

\section{GC-MS Analysis of Aqueous Extract Sample}

\section{Analysis of Aqueous Extract on Polar Column}

The aqueous extract contains; Stigmasterol, Cholest-5-en-3-ol also known as Cholesterol that has wound healing property (40) and skin protector activities, Ergesto-5,22-dien-3-ol, (3- Beta, $22 \mathrm{Z}$ ) and Cholesta-4,6-dien-3-ol ( 3.Beta ) were also observed (Table 9).

Table 9: Aqueous extract's compounds on polar column.

\begin{tabular}{lll}
\hline $\begin{array}{l}\text { Retention } \\
\text { times }\end{array}$ & Compound & $\%$ \\
\hline 16.69 & Diethyl phthalate & 14.28 \\
20.50 & Retinol, acetate (Vitamin A acetate ) & 2.85 \\
20.67 & Pregnalone acetate & 8.92 \\
& Globulol & 3.57 \\
21.07 & 5-Alpha, Ergost-8 (14 )-en & 3.00 \\
21.42 & Androstane-3-ol, 9-methyl-( 3.Beta, 5.Alpha ) & 3.57 \\
21.62 & Flavon 4'-OH, 5-OH, 7-di-O-glycoside & \\
& Carveol & 7.85 \\
22.39 & Ergesto-5,22-dien-3-ol, & 2.85 \\
23.40 & (3- Beta, 22 Z ) & 16.07 \\
25.33 & Stigmasterol & 39.28 \\
26.06 & Cholesta-4,6-dien-3-ol ( 3.Beta ) & 3.57 \\
32.50 & Cholest-5-en-3-ol (3. Beta ) & \\
\hline
\end{tabular}




\section{Analysis of Aqueous Extract on Nonpolar Column}

Table 10. Aqueous extract's compounds on nonpolar column.

\begin{tabular}{lll}
\hline Retention times & Compound & $\%$ \\
\hline 21.641 & Hexanedioic acid dioctyl ester & 24.28 \\
19.990 & Myristin, 2,3-diacetin & 12.15 \\
18.553 & Benzoic acid, 2,3-dihydroxymethyl ester & 1.93 \\
16.570 & Octadecanoic acid & 1.61 \\
11.241 & L-Glutamic acid & 3.37 \\
10.591 & Coumarin & 15.54 \\
10.356 & Xsanthine riboside & 1.49 \\
9.964 & 3-Hexendioic acid & 1.69 \\
9.594 & 1,2,3-trihydroxybenzene & 3.35 \\
8.104 & Octanal & 1.20 \\
7.399 & 4-Hepten-3-one, 5-methyl & 4.78 \\
6.252 & 4H-Pyran-4-one, 2,3-dihydro-3,5-dihydroxy-6-methyl & 11.23 \\
5.203 & 3-Penten-2-one (or unidentified compound) & 3.55 \\
\hline
\end{tabular}

Hexanedioic acid dioctyl ester known as dioctyl adipate is a plasticizer and it is the highest amount of the extract. Myristin, 2,3-diacetin, and Coumarin are the other main components in the extract. Coumarin is a pharmaceutical and fragrance active compound. 4H-Pyran-4-one, 2,3dihydro-3,5-dihydroxy-6-methyl (DDMP) having strong antioxidant activity was seen in the aqueous extract. 3-Penten-2-one is a flavoring agent. 1,2,3-trihydroxy benzene with the synonym Pyrogallol is used for hair dyeing and antiseptic purposes. L-Glutamic acid is an important biological and active nutritional compound. Xanthine riboside, Xanthosine is an important nucleoside (Table 10).

\section{GC-MS Analysis of Methanolic Extract}

Analysis of Methanolic Extract on Polar Column

Analysis results were given in a detailed form in Table 11. Some of the important constituents were mentioned. Many pharmaceutical drugs include 2-pyrrolidinone compound. 2,3-dihydro3,5-dihydroxy-6-methyl-4H-pyran-4-one(41) has antioxidant activity. 2-Furancarboxaldehyde (42) is used as a flavoring agent. a-L-Mannopyranoside methyl 6-deoxy-2,4-di-O-methyl acetate has several physiological (43) activities. 4-Methoxybenzaldehyde dimethyl acetal is used for pharmaceutical applications and food flavor industry. 1,2,4-Benzenetriol is also known as hydroxyquinol, and it is the biodegradation product of an important antioxidant of catechin (44). LC-MS analysis and MS analysis showed glucose or galactose. The GC-MS analysis also exhibited mannose's presence and mannopyranoside. Pyridazine is a pharmacophore that is found in herbicides. Iron, monocarbonyl-(1,3-butadiene-1,4-dicarbonic acid, diethyl ester), a, a'-dipyridyl is an organometallic complex that is found in some plants. Anti-4-aza- $\beta$-homo- $5 a^{\prime}$-cholestane3-one and 3-aza- $\beta$-homo-5a'-cholestane-4-one are aza sterols that are noticed in the plant. Some aza sterols show inhibitor activities. Benzenedicarboxylic esters are (45) used in cosmetics and fragrance industry. 2-Cyclohexen-1-one, 4-hydroxy-3,5,5-trimethyl-4-(3-oxo-1-butenyl) has high conjugation that is in the volatile compounds may give the plant's odor. D-Xylose is 
also found in the plant as a carbohydrate. Tetradecanoic acid, 9-octadeceneoic acid, pentadecanoic acid, tridecanoic acid, hexadecanoic acid, 9,12-octadecadienoic acid $(Z, Z)$ are saturated and unsaturated fatty acid components of methyl alcoholic extract. Methanone, diphenyl with the common name benzophenone prevents UV light. This feature may be evaluated for plant's usage as a natural preservative for food. 1,2-Benzenedicarboxylic acid, bis(2-methyl propyl) ester is used as a plasticizer and has light and heat stability. During the extract preparation, it was observed that extract was too thick after vaporization to remove. This condition may be a result of these types of plasticizer that found in plant extract. The plant has several kinds of long unsaturated chain fatty acid and long chain fatty acid's di or tri methyl esters and long linear chain paraffin as; hexadecanoic acid, tetradecandioic acid dimethyl ester, 9,12,15-octadecatrienoic acid, 2-pentadecanone, 6,10,14-trimethyl. The plant also consists of unsaturated fatty acid amide like 9-octadecenamide and different esters as hexanedioic acid, bis (2-ethyhexyl)ester, 9,12-octadecadienoic acid (Z,Z)-2,3-bis[(trimethylsilyl)oxy]propyl ester and 9,12,15-octadecatrienoic acid. Quercetin 7,3',4'-trimethoxy was seen in methanolic extracts' GC-MS analysis. Benzene, 1,1'-sulfonyl(bis[4-chloro])- is a heterocyclic organic fragment. 1'-(4methoxyphenyl)spiro(naphthalene-1 $(2 \mathrm{H}), 2\left(1^{\prime} \mathrm{H}\right)$-naphtho[2,1-b]furan-2-one-oxime is a hetero polyaromatic compound. Cholest-5-en-3-ol (3a) with the common name cholesterol is a precursor for steroid hormones. Cholestane-3,5-diol, 5-acetate and cholesta-4,6-dien-3-ol, (3a) are other sterol derivatives. 1,2-dihydrodiphenylphthalazine was seen in several minutes. Androstane-11,17-dione-3-[(trimethylsilyl)oxy]-17-[0-(phenylmethyl)oxime $\left(3 a^{\prime}, 5 a^{\prime}\right)$, is an important sterol derivative may have antagonist activity against rat prostatic androgen receptor and favors the reduction of estrogens and androgens. Silane, trimethyl[[(3a)-stigmast-5-en-3$\mathrm{yl}$ ]oxy] is a Si derivative of phytosterol stigmasterol. Stigmasterol is used for the production of synthetic progesterone $(46,47,48)$. Stigmast-5-en-3-ol, $(3 a, 24 S)$ - with the common name of beta-Cytosterol has reducing potent for benign prostatic hyperplasia and blood cholesterol level(49). Stigmast-7-en-3-ol is another type of phytosterol. Cholest-7-en-3-ol, (Lathasterol) has oxidoreductase property. Dodecamethyl naphthacene is linear alkyl bounded form of polycyclic aromatic compound, and it is used in electronic conducting and light emitting industry. 
Table 11. Methanolic extract's compounds on the polar column.

\begin{tabular}{|c|c|c|}
\hline $\begin{array}{l}\text { Retention } \\
\text { times }\end{array}$ & Compound & $(\%)$ \\
\hline 3.10 & 2,3-Dihydro-3,5-dihydroxy-6-methyl-4H-pyran-4-one & 0.17 \\
\hline 3.22 & 2-Pyrrolidinone, 5-hydroxymethyl & 0.55 \\
\hline 3.45 & 2-Furancarboxaldehyde & 1.63 \\
\hline 3.60 & 4-Methoxybenzaldehyde & 0.31 \\
\hline 3.89 & $\begin{array}{l}\text { a-L-Mannopyranoside methyl- 6-deoxy-2,4-di-O-methyl } \\
\text { acetate }\end{array}$ & 0.22 \\
\hline 3.90 & Benzene, (2,2,2-trichloro ethyl) & 0.19 \\
\hline 4.00 & anti-4-Aza- $\beta$-homo-5a'-cholestane-3-one & 0.25 \\
\hline 4.09 & 4-Methoxybenzaldehyde dimethyl acetal & 0.18 \\
\hline 4.18 & 1,2,4-Benzenetriol & 0.33 \\
\hline 4.50 & 3-Aza- $\beta$-homo-5a'-cholestane-4-one & 0.20 \\
\hline 4.59 & Mannopyranoside methyl 6-deoxy-2,4-dimethylacetate & 0.22 \\
\hline 4.70 & Pyridazine & 0.13 \\
\hline 4.89 & d-Mannose & 0.25 \\
\hline 4.91 & 1,3,5-Triazine-2,4-diamine, 6-chloro-N-ethyl & 0.17 \\
\hline 5.29 & Spirost-8-en-11-one-3-hydroxy & 0.35 \\
\hline 5.32 & D-Xylose & 0.32 \\
\hline 5.50 & Methanone, diphenyl & 0.66 \\
\hline 5.57 & Heptacosanoic acid methyl ester & 0.11 \\
\hline 5.70 & Tetradecanoic acid & 0.23 \\
\hline 5.89 & $\begin{array}{l}\text { 2-Cyclohexen-1-one, 4-hydroxy-3,5,5-trimethyl-4-(3-oxo-1- } \\
\text { butenyl)- }\end{array}$ & 0.75 \\
\hline 6.03 & 2-Pentadecanone & 0.32 \\
\hline 6.13 & 1,2-Benzenedicarboxylic acid, bis(2-methylpropyl) ester & 0.56 \\
\hline 6.36 & Heptacosanoic acid methyl ester & 0.19 \\
\hline 6.48 & Hexadecanoic acid & 1.44 \\
\hline 6.78 & Tetradecandioic acid dimethyl ester & 0.57 \\
\hline 6.81 & $9,12,15$-Octadecatrienoic acid & 0.20 \\
\hline 7.09 & 9-Octadecenoic acid (Z) & 0.33 \\
\hline 7.12 & 9,12 -Octadecadienoic acid & 0.21 \\
\hline 7.54 & 13-Docosenoic acid & 0.17 \\
\hline 7.55 & Benzene, 1,1'-sulfonyl(bis[4-chloro- & 0.13 \\
\hline 7.80 & Eicosanoic acid & 0.24 \\
\hline 7.85 & 9-Octadecenamide & 0.19 \\
\hline 7.88 & Quercetin 7,3',4'-trimethoxy & 0.86 \\
\hline 7.89 & Hexanedioic acid, bis (2-ethylhexyl)ester & 0.37 \\
\hline 7.89 & $\begin{array}{l}9,12 \text {-Octadecadienoic acid }(Z, Z)-2,3- \\
\text { bis }[\text { (trimethylsilyl)oxypropyl ester }\end{array}$ & 0.25 \\
\hline 8.31 & Hexadecanoic acid, 2-hydroxy-1-(hydroxymethyl)ethyl ester & 0.14 \\
\hline 8.36 & 1,2-Benzenedicarboxylic acid, bis(2-ethylhexyl)ester & 0.21 \\
\hline 9.24 & Spirost-8-en-11-one-3-hydroxy(3á,5à,14á,20á,22á,25R) & 0.38 \\
\hline 9.88 & $\begin{array}{l}1^{\prime}-(4-M e t h o x y p h e n y l) \text { spiro } \text { naphthalene-1(2H), } 2^{\prime}\left(1^{\prime} \mathrm{H}\right)- \\
\text { naphtho[2,1-b]furan\} 2-one oxime }\end{array}$ & 0.13 \\
\hline 10.45 & $\begin{array}{l}\text { Iron, monocarbonyl-(1,3-butadiene-1,4-dicarbonic acid, } \\
\text { diethyl ester) a,a'-dipyridyl }\end{array}$ & 0.11 \\
\hline 11.86 & Cholest-5-en-3-ol (3á) & 0.26 \\
\hline 11.42 & Cholesta-4,6-dien-3-ol, (3á) & 0.13 \\
\hline 11.42 & Silane, trimethyl[[(3á)-stigmast-5-en-3-yl]oxy] & 0.15 \\
\hline 12.94 & $\begin{array}{l}\text { Androstane-11,17-dione, 3-[(trimethylsilyl)oxy]-, 17-[0- } \\
\text { (phenylmethyl)oxime], (3à,5à) }\end{array}$ & 0.21 \\
\hline 12.76 & 2,2-Dimethyl)-7-ethoxy-4-chromanone ethylene dithioketal & 0.13 \\
\hline 14.00 & Stigmast-5-en-3-ol, (3á,24S)- & 0.65 \\
\hline 14.02 & Stigmast-7-en-3-ol & 0.11 \\
\hline 14.03 & Cholest-7-en-3-ol & 0.11 \\
\hline 14.06 & Dodecamethyl naphthacene & 0.19 \\
\hline 14.10 & $\begin{array}{l}\text { Pregnane-3,11,20,21-tetrol, cyclic 20,21-(butyl boronate), } \\
\text { (3à,5á,11á,20R)- }\end{array}$ & 0.10 \\
\hline 14.58 & $\begin{array}{l}9,12 \text {-Octadecadienoic acid }(Z, Z)-2,3- \\
\text { bis[(trimethylsilyl)oxypropyl ester }\end{array}$ & 0.17 \\
\hline
\end{tabular}




\begin{tabular}{|c|c|c|}
\hline $\begin{array}{l}\text { Retention } \\
\text { times }\end{array}$ & Compound & $(\%)$ \\
\hline 16.11 & 1,2-Dihydro-1,4-diphenylphthalazine & 0.09 \\
\hline 18.79 & $\begin{array}{l}5,11,17,23 \text {-tetrakis(1,1-dimethylethyl)-28- } \\
\text { methoxypentacyclo[19.3.1.1(3,7).1(9,13).1(15,19)]octacosa- } \\
1(25), 3,5,7(28), 9,11,13(27), 15,17,19(26), 21,23 \text {-dodecene- } \\
25,26,27 \text {-triol }\end{array}$ & 0.16 \\
\hline 20.74 & (S)-(E)-(-)-4-Acetoxy-1-phenyl-2-dodecan-1-one & 0.12 \\
\hline
\end{tabular}

Pregnane-3,11,20,21-tetrol, cyclic 20,21-(butyl boronate), (3à,5á,11á,20R)- is a hormonal derivative. (S)-(E)-(-)-4-acetoxy-1-phenyl-2-dodecan-1-one may be responsible for flavoring property of the plant. 5,11,17,23-tetrakis (1,1-dimethylethyl)-28-methoxypentacyclo $[19 \cdot 3 \cdot 1 \cdot 1(3,7) \cdot 1(9,13) \cdot 1(15,19)] \quad$ octacosa- $(25), 3,5,7(28), 9,11,13(27), 15,17,19(26), 21,23-$ dodecene-25,26,27-triol has a huge cage like structure.

\section{Analysis of Methanolic Extract on Nonpolar Column}

$\mathrm{L}(+)$-glutamine was a major compound of methanolic extract as an amino acid and has a significant_medicinal usage for injury and illness. 4H-Pyran-4-one, 2,3-dihydro-3,5-dihydroxy6-methyl (DDMP) has strong antioxidant activity. Long chain fatty acids and derivatives were observed as Hexadecanoic acid, Oleic acid(9-Octadecenoic acid (Z)) and Pentadecanoic acid, 14methyl-, methyl ester (Table 12).

Table 12. Methanolic extract's compounds on the nonpolar column.

\begin{tabular}{lll}
\hline $\begin{array}{l}\text { Retention } \\
\text { times }\end{array}$ & Compounds & $\%$ \\
\hline 24.401 & 1,2-Benzenedicarboxylic acid, bis(2-ethylhexyl)ester & 1.13 \\
17.051 & Hexanedioic acid & 1.16 \\
18.587 & 9-Octadecenoic acid (Z) & 18.90 \\
21.600 & 4-Hexenoic acid, 6-hydroxy methyl ester & 1.16 \\
16.198 & Pentadecanoic acid, 14-methyl-, methyl ester & 8.58 \\
15.346 & 2-Pentadecanone, 6,10,14-methyl & 2.14 \\
14.340 & Hexadecanoic acid & 1.05 \\
10.453 & Xanthosine & 1.55 \\
9.517 & L-proline, 5-oxo-methyl ester or L(+)-glutamine & 37.19 \\
8.734 & 3-Penten-2-one, 3-(2-furanyl) & 1.24 \\
8.118 & Octanal & 1.30 \\
7.454 & 2-Propyl-2-pentenal & 2.05 \\
6.627 & 1,3-Cyclopentanediol & 2.82 \\
6.237 & 4H-Pyran-4-one, 2,3-dihydro-3,5-dihydroxy-6-methyl & 8.14 \\
5.189 & 2-Hexanone, 3-methyl-4-methylene & 4.23 \\
4.858 & 2(3H)-Furanone, dihydro-4-hydroxy & 1.22 \\
4.013 & 4H-Pyran-4-one & 1.15 \\
\hline
\end{tabular}

\section{Analysis of Flavonoid Compounds}

Aqueous extract comprises mainly myricetin and its derivatives as flavonoids. Myricetin has more $\mathrm{OH}$ groups than quercetin, so it is more soluble in the aqueous phase. Both quercetin and kaempferol have less $\mathrm{OH}$ groups than myricetin, and both of them are less soluble than myricetin 
in the aqueous phase. The ethyl alcohol phase consists of more quercetin and kaempferol than the corresponding aqueous phase (Table 13). Separated glycosides were seen in the hydrolyzation process. Therefore, there is more than one single flavonoid glycoside linkage. Multiple glycosides were connected to flavonoids from different sides not only from the 3rd or 6th centers. Greater flavonoids with various glycosides were found in this plant. This case was supported by LC-MS analysis of different plant samples' with large molecular mass peaks (796.57-784.01) of possible flavonoid glycosides. Due to the solubility, aqueous extract hydrolysate has more separated glycosides and glucuronic acid than ethyl alcohol extract hydrolysate. Aqueous extract consists of more glucuronic acid. This acid may occur as its $\mathrm{K}, \mathrm{Mg}$, $\mathrm{Na}$ salts. Ethyl alcohol extract-hydrolysate contains mainly isoquercetin, quercetin, and myricetin-3-0-glucoside. The analysis also showed the presence of quercetin-3-O-(6"-galloyl)galactoglucoside, quercetin-3-0-(6"-galloyl)-galactoglucuronide or myricetin-3-0-(6"-galloyl)galactoglucoside or ellagic acid derivative. Direct dry plant hydrolysate contains both myricetin and quercetin in approximate amounts. HPLC analysis of short wavelengths shows mainly flavonoids like quercetin and its derivatives. Anthocyanidins like kerocyanine chloride and peonidine chloride are also found but not so much as in HPLC analysis run at long wavelengths. HPLC analysis of long wavelengths exhibited anthocyanidins like cyanine, cyanidine glucoside or kerocyanine chloride. Anthocyanidins are pigment source of plant's flowers which are pink to purple. Long wavelength analysis could not show the flavonoid content as quercetin and the others. Plant's carbohydrates are mainly glucose and galactose. Glucuronic acid is also observed in LC-MS analysis. GC-MS analysis of methanolic extract showed additionally xylose and mannose as carbohydrates.

Table 13. Flavonoid compounds of Epilobium angustifolium L. extracts.

\begin{tabular}{|c|c|c|c|c|c|c|c|c|c|}
\hline \multirow[t]{2}{*}{ Flavonoids } & \multicolumn{9}{|c|}{ Extracts and Analysis $(\lambda=n m)$} \\
\hline & $\begin{array}{l}\text { Methyl } \\
\text { Alcohol } \\
\text { extract } \\
\text { HPLC }\end{array}$ & $\begin{array}{l}\text { Ethyl } \\
\text { Alcohol } \\
\text { Extract } \\
\text { LC-MS }\end{array}$ & $\begin{array}{l}\text { Ethyl } \\
\text { Alcohol } \\
\text { hydrolysate } \\
\text { LC-MS }\end{array}$ & HPLC & $\begin{array}{l}\text { LC- } \\
\text { MS }\end{array}$ & MS & $\begin{array}{l}\text { Aqueo } \\
\text { Extrac } \\
\text { Hydrol } \\
\text { HPLC }\end{array}$ & $\begin{array}{l}\text { IS } \\
\text { ysate } \\
\text { LC-MS }\end{array}$ & $\begin{array}{l}\text { Direct Plant } \\
\text { Hydrolysate } \\
\text { LC-MS }\end{array}$ \\
\hline Catechin & $\begin{array}{l}+, \\
(280)\end{array}$ & - & - & $\begin{array}{l}+ \\
(280)\end{array}$ & - & - & - & - & - \\
\hline Cyanine & $\begin{array}{l}+, \\
(276) \\
+ \\
(514)\end{array}$ & - & - & $\begin{array}{l}+, \\
(276- \\
514)\end{array}$ & - & - & - & - & - \\
\hline $\begin{array}{l}\text { Cyanidin } \\
\text { glucoside }\end{array}$ & $\begin{array}{l}+, \\
(522) \\
+ \\
(281)\end{array}$ & - & - & $\begin{array}{l}+, \\
(281- \\
523)\end{array}$ & - & - & $\begin{array}{l}+ \\
(281- \\
523)\end{array}$ & - & - \\
\hline $\begin{array}{l}\text { Delphinidin } \\
\text { chloride }\end{array}$ & $\begin{array}{l}+, \\
(272)\end{array}$ & - & - & $\begin{array}{l}+, \\
(272- \\
530)\end{array}$ & - & - & $\begin{array}{l}+, \\
(272- \\
531)\end{array}$ & - & - \\
\hline
\end{tabular}


Extracts and Analysis $(\lambda=\mathbf{n m})$

\begin{tabular}{|c|c|c|c|c|c|c|c|c|c|}
\hline & \multirow{2}{*}{$\begin{array}{l}\text { Methyl } \\
\text { Alcohol } \\
\text { extract } \\
\text { HPLC }\end{array}$} & \multirow{2}{*}{$\begin{array}{l}\text { Ethyl } \\
\text { Alcohol } \\
\text { Extract } \\
\text { LC-MS }\end{array}$} & \multirow{2}{*}{$\begin{array}{l}\text { Ethyl } \\
\text { Alcohol } \\
\text { hydrolysate } \\
\text { LC-MS }\end{array}$} & \multicolumn{3}{|c|}{ Aqueous Extract } & \multicolumn{2}{|c|}{$\begin{array}{l}\text { Aqueous } \\
\text { Extract } \\
\text { Hydrolysate }\end{array}$} & \multirow[t]{2}{*}{$\begin{array}{l}\text { Direct Plant } \\
\text { Hydrolysate } \\
\text { LC-MS }\end{array}$} \\
\hline & & & & HPLC & $\begin{array}{l}\text { LC- } \\
\text { MS }\end{array}$ & MS & HPLC & LC-MS & \\
\hline $\begin{array}{l}\text { Hyperoside } \\
\text { (Quercetin-3-O- } \\
\text { galactoside) }\end{array}$ & $\begin{array}{l}+,(255- \\
354)\end{array}$ & $\begin{array}{l}+, \\
(359)\end{array}$ & - & $\begin{array}{l}+ \\
(255- \\
354)\end{array}$ & - & - & $\begin{array}{l}+ \\
(255- \\
354)\end{array}$ & $\begin{array}{l}+, \\
(359)\end{array}$ & - \\
\hline $\begin{array}{l}\text { Isoquercetin } \\
\text { (Quercetin-3-O- } \\
\text { glucoside) }\end{array}$ & $\begin{array}{l}+, \\
(353) \\
+,(255- \\
353)\end{array}$ & $\begin{array}{l}+, \\
(359)\end{array}$ &,$+(359)$ & $\begin{array}{l}+ \\
(255- \\
353)\end{array}$ & $\begin{array}{l}+, \\
(359)\end{array}$ & + & $\begin{array}{l}+, \\
(255- \\
353)\end{array}$ & $\begin{array}{l}+, \\
(359)\end{array}$ & - \\
\hline Kaempferol & $\begin{array}{l}+,(257- \\
360)\end{array}$ & $\begin{array}{l}+, \\
(359)\end{array}$ & - & $\begin{array}{l}+ \\
(257- \\
360)\end{array}$ & $\begin{array}{l}+, \\
(359)\end{array}$ & + & $\begin{array}{l}+ \\
(257- \\
360)\end{array}$ & $\begin{array}{l}+, \\
(359)\end{array}$ & - \\
\hline $\begin{array}{l}\text { Kaempferol-3- } \\
\text { arabinoside }\end{array}$ & - & - & - & - & - & + & - & - & - \\
\hline $\begin{array}{l}\text { Kaempferol-3- } \\
\text { glucoside }\end{array}$ & - & $\begin{array}{l}+, \\
(359)\end{array}$ & - & - & - & - & - & $\begin{array}{l}+ \\
(359)\end{array}$ & - \\
\hline $\begin{array}{l}\text { Kaempferol-3- } \\
\text { rhamnoside }\end{array}$ & - & - & - & - & - & + & - & - & - \\
\hline $\begin{array}{l}\text { Kerocyanin } \\
\text { chloride }\end{array}$ & - & - & - & - & - & - & - & - & - \\
\hline Luteolin & - & - & - & $\begin{array}{l}+ \\
(252- \\
357)\end{array}$ & - & - & - & - & - \\
\hline Quercetin & - & $\begin{array}{l}+, \\
(359)\end{array}$ &,$+(359)$ & $\begin{array}{l}+ \\
(250- \\
355)\end{array}$ & $\begin{array}{l}+, \\
(359)\end{array}$ & + & $\begin{array}{l}+, \\
(250- \\
375)\end{array}$ & $\begin{array}{l}+ \\
359\end{array}$ & - \\
\hline $\begin{array}{l}\text { Quercetin-3-O- } \\
\text { arabinoside }\end{array}$ & - & $\begin{array}{l}+, \\
(359)\end{array}$ & - & - & - & - & - & $\begin{array}{l}+, \\
(359)\end{array}$ &,$+(359)$ \\
\hline $\begin{array}{l}\text { Quercetin-3-O- } \\
\text { (6"-galloyl)- } \\
\text { galactoside }\end{array}$ & - & - & - & - & $\begin{array}{l}+ \\
(359)\end{array}$ & - & - & - & - \\
\hline $\begin{array}{l}\text { Quercetin-3-O- } \\
\text { (6"-galloyl)- } \\
\text { galactoglucoside }\end{array}$ & - & - &,$+(359)$ & - & $\begin{array}{l}+, \\
(359)\end{array}$ & - & - & - & - \\
\hline $\begin{array}{l}\text { Quercetin-3-O- } \\
\text { glucronide }\end{array}$ & - & - & - & - & $\begin{array}{l}+, \\
(359)\end{array}$ & - & - & - & - \\
\hline $\begin{array}{l}\text { Quercetin-3-O- } \\
\text { (6"-galloyl)- } \\
\text { galactoglucronide }\end{array}$ & - & - &,$+(359)$ & - & $\begin{array}{l}+, \\
(359)\end{array}$ & - & - & - & - \\
\hline $\begin{array}{l}\text { Quercitrin } \\
\text { (Quercetin-3-O- } \\
\text { rhamnoside) }\end{array}$ & $\begin{array}{l}+,(258- \\
353)\end{array}$ & - & - & $\begin{array}{l}+ \\
(258- \\
353)\end{array}$ & $\begin{array}{l}+ \\
(359)\end{array}$ & + & $\begin{array}{l}+, \\
(250- \\
353)\end{array}$ & - &,$+(359)$ \\
\hline Myricetin & $\begin{array}{l}+,(250- \\
373)\end{array}$ & $\begin{array}{l}+, \\
(359)\end{array}$ & - & $\begin{array}{l}+, \\
(250- \\
373)\end{array}$ & $\begin{array}{l}+ \\
\text { (359) }\end{array}$ & + & $\begin{array}{l}+ \\
(250- \\
373)\end{array}$ & - &,$+(359)$ \\
\hline $\begin{array}{l}\text { Myricetin-3-O- } \\
\text { glucoside }\end{array}$ & - & $\begin{array}{l}+, \\
(359)\end{array}$ &,$+(359)$ & - & $\begin{array}{l}+, \\
(359)\end{array}$ & + & - & - & - \\
\hline
\end{tabular}


Extracts and Analysis $(\lambda=n m)$

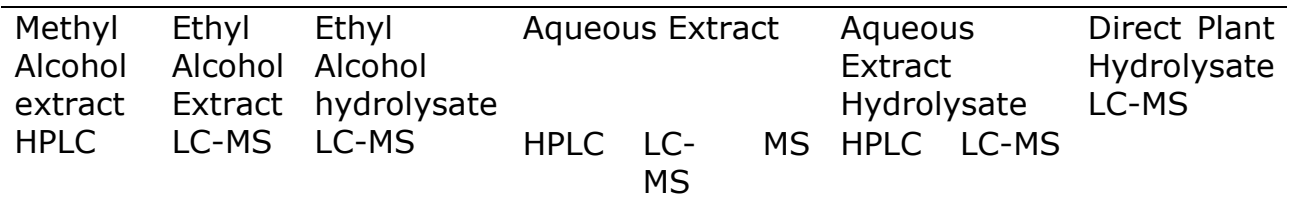

Myricetin-3-Ogalactoside

Myricetin-3-Oglucronide

Myricetin-3-O(6"-galloyl)galactoside

Myricetin-3-O(6"-galloyl)galactoglucoside Peonidin chloride + ,

(265)

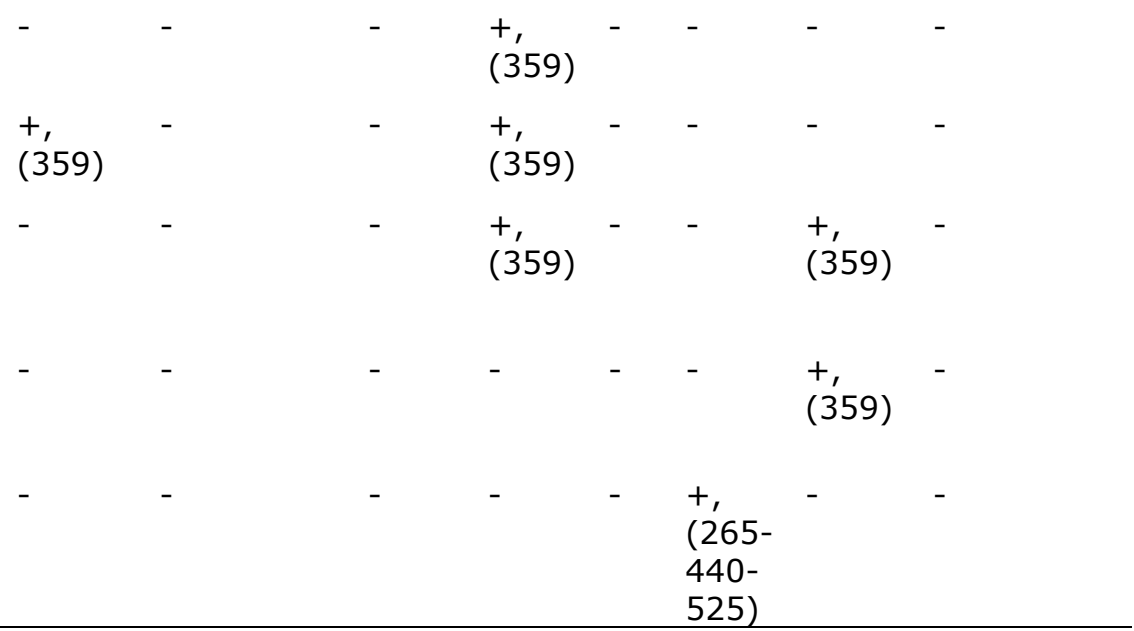

525)

\section{Fatty Acid Analysis of Plant's Hexane Extract by GC}

Butyric acid, cis-13,16-docosadienoic acid, lignoceric acid, and nervonic acid are the highest fatty acids in the GC analysis (Table 14).

Table 14: Fatty acids of hexane extract.

\begin{tabular}{lcc}
\hline Fatty acids & Retention times & \% \\
\hline Butyric acid & 3.716 & 14.59 \\
Caprylic acid & 4.390 & 1.70 \\
Caproic acid & 4.763 & 0.71 \\
Palmitic acid & 25.492 & 1.18 \\
Oleic acid & 31.294 & 0.43 \\
Linoleic acid & 32.857 & 0.95 \\
Tricosanoic acid & 40.781 & 0.65 \\
cis 13,16-docosadienoic & 41.974 & 9.01 \\
acid & 42.212 & 4.65 \\
Lignoceric acid & 43.646 & 5.30 \\
Cis 5,8,11,14,17- & & \\
eicosanoic acid & 44.410 & 6.26 \\
Nervonic acid & 51.812 & 54.59 \\
Unknown component & & \\
\hline
\end{tabular}

GC-MS analysis of methanolic extract has also provided detailed fatty acid components (Table 11 and Table 12). 9,12-octadecadienoic acid $(Z, Z)$, tetradecandioic acid dimethyl ester, hexadecanoic acid methyl ester, eicosanoic acid, 9-octadecenamide are main ones. Hexadecanoic acid was also observed in aqueous extract's GC-MS analysis. 


\section{Inorganic Element Analysis}

ICP - MS Analysis

According to the ICP-MS (Table 15) and AAS (Table 16) analysis, the plant has high amounts of $\mathrm{K}, \mathrm{Mg}, \mathrm{Na}, \mathrm{Fe}, \mathrm{Si}, \mathrm{Ca}$ and low amounts of $\mathrm{I}, \mathrm{Zn}, \mathrm{Al}, \mathrm{Mn}, \mathrm{Cu}, \mathrm{Ni}, \mathrm{Sr}$ and trace amounts of $\mathrm{Mo}$, Se. GC-MS analysis of the plant's methanolic extract showed many macromolecular organic Si ether structures, iron complexes, and alkyl iodide derivatives. Organic Si ether structures make the plant useful as natural skin peeling agent. Additionally, rich Si content allows the plant to be resistant against to fire and hard environmental conditions.

Table 15. ICP - MS analysis results.

\begin{tabular}{lll}
\hline Amount & Tea sample & $\begin{array}{l}\text { Powdered sample from } \\
\text { dry plant }\end{array}$ \\
\hline High & $\mathrm{K}, \mathrm{Mg}, \mathrm{P}, \mathrm{Na}, \mathrm{Ca}$ & $\mathrm{K}, \mathrm{Mg}, \mathrm{P}, \mathrm{Na}$ \\
amount & & \\
Low amount & $\mathrm{I}, \mathrm{Mn}, \mathrm{B}, \mathrm{Zn}, \mathrm{Ba}, \mathrm{Al}, \mathrm{Cu}, \mathrm{Sr}, \mathrm{I}, \mathrm{B}, \mathrm{Zn}, \mathrm{Ba}, \mathrm{Al}, \mathrm{Cu}, \mathrm{Ni}, \mathrm{Cr}$, \\
& $\mathrm{Rb}, \mathrm{Ni}, \mathrm{Cr}, \mathrm{Fe}, \mathrm{Ti}, \mathrm{Pb}, \mathrm{Si}$ & $\mathrm{Fe}, \mathrm{Ti}, \mathrm{Pb}, \mathrm{Si}, \mathrm{Ca}, \mathrm{Ce}, \mathrm{Rb}, \mathrm{Sr}$ \\
Trace & $\mathrm{Mo}, \mathrm{Cd}, \mathrm{Sn}, \mathrm{V}, \mathrm{Li}, \mathrm{Co}, \mathrm{Br}, \mathrm{Sc}, \mathrm{Mo}, \mathrm{Sn}, \mathrm{V}, \mathrm{Li}, \mathrm{Br}, \mathrm{Sc}, \mathrm{Se}, \mathrm{Zr}$ \\
amount & $\mathrm{Se}$ & \\
\hline
\end{tabular}

AAS Analysis

Table 16. Analysis results for the dry powdered plant.

\begin{tabular}{lccc}
\hline \multicolumn{3}{c}{ Flame spectrophotometer } \\
\hline K: $13530 \mathrm{ppm}$ & $\mathrm{Na}: 407 \mathrm{ppm}$ & Fe: $437 \mathrm{ppm}$ & Si: $85920 \mathrm{ppm}$ \\
Graphite spectrophotometer \\
Zn: $50 \mathrm{ppm}$ & Mg: $4066 \mathrm{ppm}$ & Mn: $1138 \mathrm{ppm}$ & Se: $0,315 \mathrm{ppm}$ \\
\hline
\end{tabular}

\section{Analysis of Hormonal Compounds}

Hormonal structures were particularly investigated by GC-MS analysis of aqueous (Table 10) and methanolic extracts (Table 11). Ergesto-5,22-dien-3-ol (3-beta, 22z), stigmasterol, cholesta4,6-dien-3-ol (3.beta), cholest-5-en-3-ol (3.beta), 5-alpha, ergost-8(14)-en were mainly in the aqueous extract. anti-4-aza- $\beta$-homo-5a-cholestan-3-one, androstane-11,17-dione, silane, trimethyl[(3a)-stigmast-5-en-yloxyl, cholestane-3,5-diol, stigmast-5-en-3-ol ( $\beta$-sitosterol), pregnane-3,11,20,21-tetrol were observed in the methanolic extract. 
The plant contains antiandrogenic effective sterol derivatives like anti-4-aza- $\beta$-homo-5acholestan-3-one. Cholesta-4,6-dien-3-ol has antioxidant activity. The methanolic extract has also contained cholest-5-en-3-ol as mentioned before. Cholest-5-en-3-ol with the common name cholesterol shows wound healing, skin disease repairing and skin protector activities. Betacytosterol's synonym is stigmast-5-en-3-ol. Campesterol is an antioxidant and hypocholesterolemic. Stigmaster is anti-inflammatory, antioxidant, antiviral, cancer-preventive, hypocholesterolemic and sedative among the others. Androstane-11,17-dione is used as prohormone drug to eliminate some diseases or deficiencies. 5-Alfa, ergost-8 (14 )-en is an ergosterol derivative.

\section{Phenolic Acids}

Phenolic acid contents of the plant for LC-MS analysis were decided according to the mass fragmentation values (Table 17). Ellagic acid is a principal phenolic acid in Epilobium angustifolium L. according to LC-MS analysis. Ellagic acid has antioxidant and anticancer properties $(50,51)$. Ellagic acid has several derivatives and also has DNA-binding activity $(52,53)$. 
Table 17. Phenolic acids of Epilobium angustifolium L. extracts. $(\lambda=360 \mathrm{~nm})$

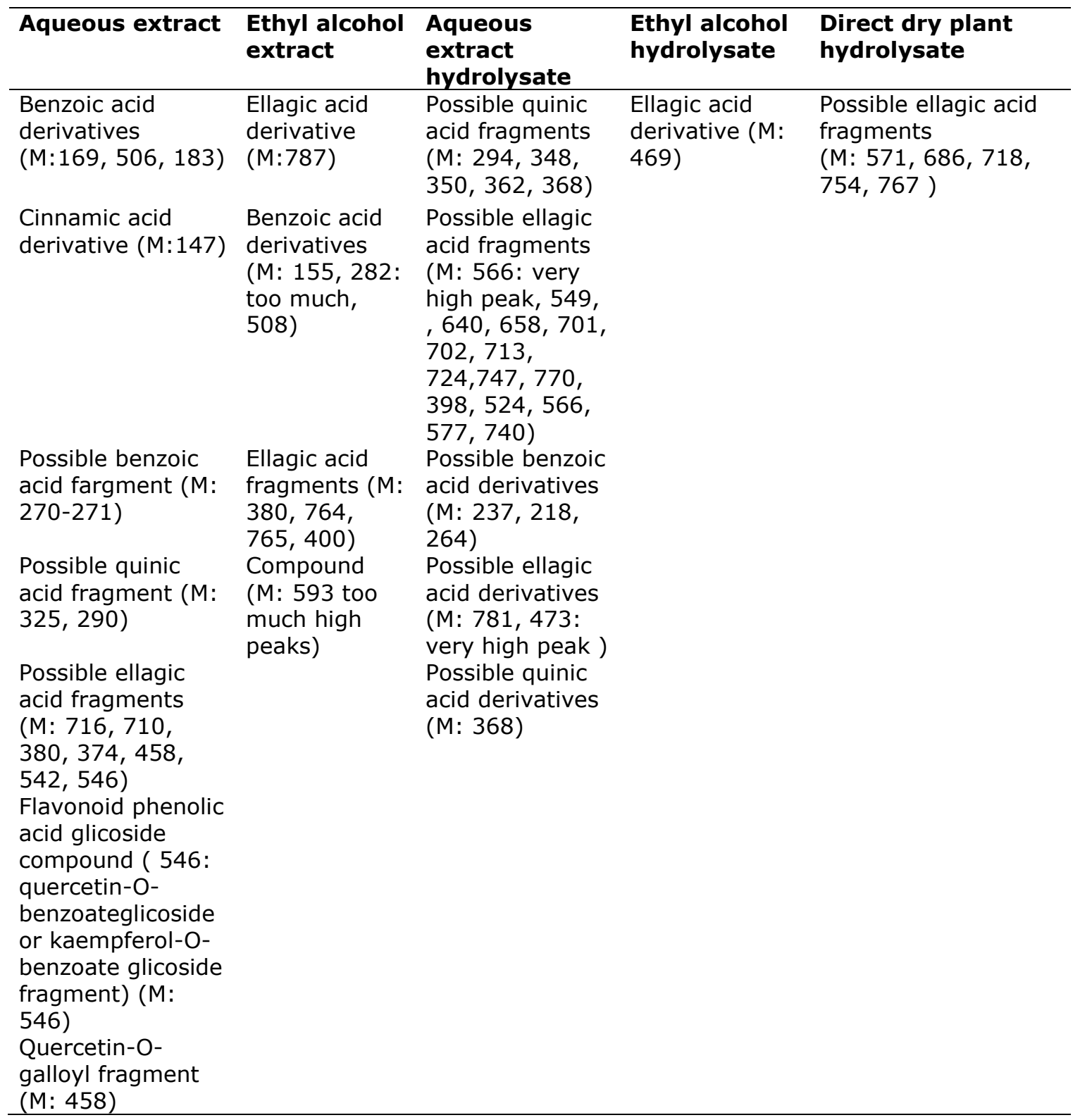

\section{CONCLUSION}

In this study, aqueous, methanolic, and ethanolic extracts of Epilobium angustifolium L. were investigated for their chemical structures and biological activities like DNA binding cleavage, antioxidant, antibacterial and antifungal activities for the probability of medicinal usage.

In the literature survey, there are some studies about phytochemistry, pharmacology and traditional uses of different Epilobium species(54) but no report about DNA -binding activity and inorganic elements of this plant. Epilobium angustifolium $L$. in this study can be proposed as a source of natural antioxidant and several cancer enzyme inhibitors in pharmaceutical, cosmetics 
and food industries. The high value of antioxidant, DNA cleavage, hormones and fatty acids may support the usage of Epilobium angustifolium L. extracts in folk medicine.

DNA interaction is one of the criteria for being an anti-cancer agent. Due to the pharmaceutical reports, if a damaged DNA would be bound by any chemical or phyto agent, the cancer cells were diminished (55).

New structures were also observed by the LC-MS analysis in addition to known flavonoids. These structures were ellagic acid and its derivatives. According to LC-MS analysis, bigger structural phenolic acid derivatives were observed in the plant. The anticancer and immune system enhancing substances (56) were generally described as containing cyclic molecules and various heteroatoms $(\mathrm{O}, \mathrm{N}, \mathrm{S}, \mathrm{Cl}, \mathrm{F}, \mathrm{I})$. Cyclic and macromolecular structures act as a trap for cancerous DNA. In this way cancer, DNA's growth is inhibited. Such agents exhibit DNA-binding activity. The methanolic extract is richer than ethanolic extract for phenolic acid content, but both extracts showed DNA-binding activity (methanolic extract binds effectively to DNA at the first two highest amounts of concentration where ethanolic extract binds less efficient but at the first three amounts of concentration. (Figure 1) The extracts have been found to be very active via binding to pBR322 plasmid DNA. Inorganic elements can be active centers for biological activities.

$\mathrm{K}, \mathrm{Si}, \mathrm{Mg}, \mathrm{Mn}, \mathrm{P}, \mathrm{Fe}$, and $\mathrm{Na}$ levels were the main inorganic elements of infusion tea and dry powdered plant sample. I, Zn, B, Al, Cu, N, Cr levels were lower. All these inorganics may be important active centers. GC-MS analysis of methanolic extract exhibited several Si-organo compounds. This feature may make the plant serve beneficial for cosmetic purposes.

Both methanolic and ethanolic extracts were studied against 11 bacteria and 3 fungi for their antimicrobial activities. B. cereus, S. typhimurium, E. hirae, and $P$. vulgaris are not tested before. The ethanolic extract exhibited good antibacterial activity against Proteus vulgaris. Plant extracts are as effective as antimicrobial agents like ampicillin and chloramphenicol.

Antifungal activities were not observed against C. albicans, C. tropicalis, C. krusei fungi. The methanolic extract exhibited the highest phenolic content.

Phenolic compounds of the plants are significant because of their hydroxyl groups against radicals (57).

LC-MS, MS, and HPLC analysis were specific for flavonoids. HPLC analysis demonstrated that methanolic extract has mainly quercetin and its glycosides while aqueous extract has myricetin 
as the main flavonoid. The plant also includes some anthocyanidins like cyanine, catechin, peonidin chloride and delphinidin chloride.

The plant has several sterols. Cholest-5-en-3-ol (cholesterol), stigmasterol, cholesta-4,6-dien3-ol, $\beta$-cytosterol, anti-4-aza- $\beta$-homo-5a-cholestane-3-one and androstane-11,17-dione are the main ones.

Sterols have anti-cancer and immune regulatory effects (58). Epilobium angustifolium L. has several fatty acids. Butyric acid, cis-13.16-docosadienoic acid, lignoceric acid and nervonic acid are the highest ones according to GC analysis of hexane extract of the plant. GC-MS analysis of methanolic extract proved saturated and unsaturated acids and their esters. Oleic acid, stearic acid, tetradecanoic acid, hexadecanoic acid, 9, 12-octadecadienoic acid, 9,12,15octadecatrienoic acid are the main fatty acids.

The plant contains glucose, galactose, mannose, xylose, glucuronic acid as carbohydrates in the form of glycosides. Most of them may be connected to flavonoids. The hydrolysate samples showed both free carbohydrates and flavonoid glycoside residues. This condition makes the plant more cyclic, and the more cyclic form enriches the plant regarding anti-cancer and other bioactivities like DNA-binding, antimicrobial, antifungal, and antioxidant properties (59). High antioxidant active herbal substances can also be used as natural preservatives in food and cosmetics to prevent UV light-induced degradation, microbial spoilage, and deterioration during storage.

The antioxidant activity supports antimicrobial activity. Epilobium angustifolium L. was found rich in total phenolic content and antioxidant activity as in vitro in this study. There are no data about antioxidant activity of methanolic extract, but aqueous and ethanolic extracts were investigated (60). Both high antioxidant and antimicrobial data are compatible with each other. According to the in vitro analysis of this study, good results were obtained with Epilobium angustifolium $L$. as a potential prodrug with its antioxidant, antimicrobial and DNA-binding activities, it can be an anticancer agent. This plant can be used among the people in the form of tea or salad or vegetable for several health and pharmaceutical purposes. Its drug form can be produced in the medicinal industry from its aqueous, methanolic or ethanolic extracts.

It is suggested that whole plant extracts may be more responsible than isolated compounds for these synergistic health effects of Epilobium angustifolium $L$. due to obtained results and chemical composition in this study. This opinion is also supported by some literature (61). 


\section{ACKNOWLEDGEMENTS}

This research was supported by Istanbul University Scientific Research Projects division with the project number T- $700 / 30062005$.

\section{REFERENCES}

1. Kumar S, Yadav A, Yadav M, Yadav JP. Effect of climate change on phytochemical diversity, total phenolic content and in vitro antioxidant activity of Aloe vera (L.) Burm. f. BMC research notes. 2017;10(1):60.

2. Hiermann $A$, Juan $H$, Sametz W. Influence of Epilobium extracts on prostaglandin biosynthesis and carrageenin induced oedema of the rat paw. Journal of ethnopharmacology. 1986;17(2):161-169.

3. Juan $\mathrm{H}$, Sametz $\mathrm{W}$, Hiermann A. Anti-inflammatory effects of a substance extracted from Epilobium angustifolium. Inflammation Research. 1988;23(1):106-107.

4. Vitali F, Fonte G, Saija A, Tita B. Inhibition of intestinal motility and secretion by extracts of Epilobium spp. in mice. Journal of ethnopharmacology. 2006;107(3):342-348.

5. Tita B, Abdel-Haq H, Vitalone A, Mazzanti G, Saso L. Analgesic properties of Epilobium angustifolium, evaluated by the hot plate test and the writhing test. Il Farmaco. 2001;56(5):341343.

6. Hiermann $A$, Reidlinger $M$, Juan $H$, Sametz $W$. Isolation of the antiphlogistic principle from Epilobium angustifolium. Plant Med. 1991 Aug;57(4):357-60.

7. Hiermann A, Schramm H, Laufer S. Anti-inflammatory activity of myricetin-3-O-beta-D-glucronide and related compounds. Inflam Res. 1998;47:421-7.

8. Stolarczyk M, Naruszewicz M, Kiss AK. Extracts from Epilobium sp. herbs induce apoptosis in human hormone-dependent prostate cancer cells by activating the mitochondrial pathway. Journal of Pharmacy and Pharmacology. 2013;65(7):1044-1054.

9. Ducrey B, Marston A, Göhring S, Hartmann R, Hostettmann K. Inhibition of 5a-reductase and aromatase by the ellagitannins oenothein A and oenothein B from Epilobium species. Planta medica. 1997;63(02):111-114.

10. Kiss A, Kowalski J, Melzig M. Induction of neutral endopeptidase activity in PC-3 cells by an aqueous extract of Epilobium angustifolium L. and oenothein B. Phytomedicine. 2006;13(4):284289.

11. Vitalone A, McColl J, Thome D, Costa LG, Tita B. Characterization of the effect of Epilobium extracts on human cell proliferation. Pharmacology. 2003;69(2):79-87.

12. Anonymous. EMA/HMPC/712510/2014 Assessment report on Epilobium angustifolium L. and /or Epilobium parviflorum Schreb. Based on Article 16d(1), Article $16 \mathrm{f}$ and Article 16h of Directive 2001/83/EC as amended (traditional use). Committtee on Herbal Medicinal Products; 2015.

13. Steck W, Hetherington M. Oenothein medicaments. US 6528490 B2, 2003. p. 11.

14. Sakagami H, Jiang $Y$, Kusama K, Atsumi T, Ueha T, Toguchi M, et al. Cytotoxic activity of hydrolyzable tannins against human oral tumor cell lines-a possible mechanism. Phytomedicine. 2000;7(1):39-47.

15. Miyamoto K, Nomura M, Sasakura M, Matsui E, Koshiura R, Murayama T, et al. Antitumor activity of oenothein B, a unique macrocyclic ellagitannin. Cancer Science. 1993;84(1):99-103. 
16. Miyamoto K, Nomura M, Murayama T, Furukawa T, Hatano T, Yoshida T, et al. Antitumor activities of ellagitannins against sarcoma-180 in mice. Biological and Pharmaceutical Bulletin. $1993 ; 16(4): 379-387$.

17. Rauha J-P, Remes S, Heinonen M, Hopia A, Kähkönen M, Kujala T, et al. Antimicrobial effects of Finnish plant extracts containing flavonoids and other phenolic compounds. International journal of food microbiology. 2000;56(1):3-12.

18. Battinelli L, Tita B, Evandri MG, Mazzanti G. Antimicrobial activity of Epilobium spp. extracts. Il Farmaco. 2001;56(5):345-348.

19. Kosalec I, Kopjar N, Kremer D. Antimicrobial activity of willowherb (Epilobium angustifolium L.) leaves and flowers. Current drug targets. 2013;14(9):986-991.

20. Webster D, Taschereau P, Belland RJ, Sand C, Rennie RP. Antifungal activity of medicinal plant extracts; preliminary screening studies. Journal of Ethnopharmacology. 2008;115(1):140-146.

21. Kähkönen MP, Hopia AI, Vuorela HJ, Rauha J-P, Pihlaja K, Kujala TS, et al. Antioxidant activity of plant extracts containing phenolic compounds. Journal of agricultural and food chemistry. $1999 ; 47(10): 3954-3962$.

22. Štajner D, Popović B, Boža P. Evaluation of willow herb's (Epilobium angustofolium L.) antioxidant and radical scavenging capacities. Phytotherapy research. 2007;21(12):1242-1245.

23. Kiss AK, Bazylko A, Filipek A, Granica S, Jaszewska E, Kiarszys U, et al. Oenothein B's contribution to the anti-inflammatory and antioxidant activity of Epilobium sp. Phytomedicine. $2011 ; 18(7): 557-$ 560 .

24. Schepetkin IA, Kirpotina LN, Jakiw L, Khlebnikov AI, Blaskovich CL, Jutila MA, et al. Immunomodulatory Activity of Oenothein B Isolated from Epilobium angustifolium. The Journal of Immunology. 2009 Nov 15;183(10):6754-66.

25. Myagmar B-E, Aniya Y. Free radical scavenging action of medicinal herbs from Mongolia. Phytomedicine. 2000;7(3):221-229.

26. Miyamoto K-I, Murayama T, Nomura M, Hatano T, Yoshida T, Furukawa T, et al. Antitumor activity and interleukin-1 induction by tannins. Anticancer research. 1992;13(1):37-42.

27. Anonymous. Untitled [Internet]. [cited 2015 Aug 19]. Available from: http://montana.plantlife.org/species/epilob_angus.htm

28. Dzwonko Z, Loster S, Gawroński S. Impact of fire severity on soil properties and the development of tree and shrub species in a Scots pine moist forest site in southern Poland. Forest Ecology and Management. 2015;342:56-63.

29. Gurova K. New hopes from old drugs: revisiting DNA-binding small molecules as anticancer agents. Future oncology. 2009;5(10):1685-1704.

30. Anonymous. Cancer Fact Sheet No:297. World Health Organization; 2014.

31. Anonymous. Defining Cancer. National Cancer Institute; 2014.

32. Braca A, De Tommasi N, Di Bari L, Pizza C, Politi M, Morelli I. Antioxidant principles from bauhinia $t$ arapotensis. Journal of natural products. $2001 ; 64(7): 892-895$.

33. Siddhuraju P, Becker K. Antioxidant properties of various solvent extracts of total phenolic constituents from three different agroclimatic origins of drumstick tree (Moringa oleifera Lam.) leaves. Journal of agricultural and food chemistry. 2003;51(8):2144-2155.

34. Dinnis T, Madeira V, Almeida L. Action of phenolic derivative (acetoaminophene salycilate and 5amino solycilate as inhibitors of membrane lipid peroxidation and as peroxyl radical scavengers). Arch Biochem Biophy. 1994;315:161-169. 
35. Hertog MG, Hollman PC, Venema DP. Optimization of a quantitative HPLC determination of potentially anticarcinogenic flavonoids in vegetables and fruits. Journal of Agricultural and Food Chemistry. 1992;40(9):1591-1598.

36. Hossain Z, Huq F. Studies on the interaction between Ag+ and DNA. Journal of inorganic biochemistry. 2002;91(2):398-404.

37. Cutter CN. Antimicrobial effect of herb extracts against Escherichia coli O157: H7, Listeria monocytogenes, and Salmonella typhimurium associated with beef. Journal of Food Protection. 2000;63(5):601-607.

38. Hao Y, Brackett R, Doyle M. Efficacy of plant extracts in inhibitingAeromonas hydrophilaandListeria monocytogenesin refrigerated, cooked poultry. Food Microbiology. 1998;15(4):367-378.

39. Puupponen-Pimiä R, Nohynek L, Meier C, Kähkönen M, Heinonen M, Hopia A, et al. Antimicrobial properties of phenolic compounds from berries. Journal of applied microbiology. $2001 ; 90(4): 494-$ 507.

40. Anonymous. American Journal of Pathology, news release. American Journal of Pathology; 2012.

41. Yu X, Zhao M, Liu F, Zeng S, Hu J. Identification of 2, 3-dihydro-3, 5-dihydroxy-6-methyl-4Hpyran-4-one as a strong antioxidant in glucose-histidine Maillard reaction products. Food research international. 2013;51(1):397-403.

42. Anonymous. Concise International Chemical Assessment Document 21/2-Furaldehyde, 2000. Who. int; 2000.

43. Petrović V, Car Ž, Prugovečki B, Tomić S janka, Matković-Čalogović D. Synthesis of Acylated Methyl 2-Acetamido-2-Deoxy-a-D-Mannopyranosides. Journal of carbohydrate chemistry. 2006;25(89):685-695.

44. Hopper W, Mahadevan A. Degradation of catechin by Bradyrhizobium japonicum. Biodegradation. $1997 ; 8(3): 159-165$.

45. Api A. Toxicological profile of diethyl phthalate: a vehicle for fragrance and cosmetic ingredients. Food and Chemical Toxicology. 2001;39(2):97-108.

46. Wilt TJ, Ishani A, MacDonald R, Stark G, Mulrow CD, Lau J. Beta-sitosterols for benign prostatic hyperplasia. The Cochrane Library. 1999;

47. Kim T-H, Lim H-J, Kim M-S, Lee MS. Dietary supplements for benign prostatic hyperplasia: An overview of systematic reviews. Maturitas. 2012;73(3):180-185.

48. Sundararaman P, Djerassi C. A convenient synthesis of progesterone from stigmasterol. The Journal of organic chemistry. 1977;42(22):3633-3634.

49. Rudkowska I, AbuMweis SS, Nicolle C, Jones PJ. Cholesterol-lowering efficacy of plant sterols in low-fat yogurt consumed as a snack or with a meal. Journal of the American College of Nutrition. $2008 ; 27(5): 588-595$.

50. Anonymous. "Ellagic acid". . November 2008. Retrieved August 2014 [Internet]. American Cancer Society; 2008. Available from:

http://www.cancer.org/treatment/treatmentsandsideeffects/complementaryandalternativemedicine /dietandnutrition/ellagic-acid

51. Anonymous. 187 fake cancer" cures" consumers should avoid. US Food and Drug Administration; 2009.

52. Shivappurkar M, Galati, Stoner G. Inhibition of N-nitrosobenzylmethylamine and a DNA-binding in cultured rat esophagus by ellagic acid. Carcinogenesis. 1988;9(7):1313-6.

53. Mandal S, Stoner GD. Inhibition of N-nitrosobenzylmethylamine-induced esophageal tumorigenesis in rats by ellagic acid. Carcinogenesis. 1990;11(1):55-61. 
54. Granica S, Piwowarski JP, Czerwińska ME, Kiss AK. Phytochemistry, pharmacology and traditional uses of different Epilobium species (Onagraceae): a review. Journal of ethnopharmacology. $2014 ; 156: 316-346$.

55. Noll DM, Mason TM, Miller PS. Formation and repair of interstrand cross-links in DNA. Chemical reviews. 2006;106(2):277-301.

56. Anonymous. Untitled [Internet]. Cancer Foundation; [cited 2015 Sep 18]. Available from: http://www.cancer.org/treatment/treatmentsandsideeffects/treatmenttypes/chemotherapy/chemot herapyprinciplesanin-depthdiscussionofthetechniquesanditsroleintreatment/chemotherapyprinciples-types-of-chemo-drugs

57. Saeed N, Khan MR, Shabbir M. Antioxidant activity, total phenolic and total flavonoid contents of whole plant extracts Torilis leptophylla L. BMC complementary and alternative medicine. $2012 ; 12(1): 221$.

58. Grattan BJ. Plant sterols as anticancer nutrients: evidence for their role in breast cancer. Nutrients. $2013 ; 5(2): 359-387$.

59. Martins P, Jesus J, Santos S, Raposo LR, Roma-Rodrigues C, Baptista PV, et al. Heterocyclic anticancer compounds: recent advances and the paradigm shift towards the use of nanomedicine's tool box. Molecules. 2015;20(9):16852-16891.

60. Kosalec I, Zovko M, Sankovic K, Kremer D, Pepeljnjak S. Antioxidant and antimicrobial activity of willow herb (Epilobium angustifolium L.). Planta Medica [Internet]. 2008 Jul [cited 2017 Jul 25];74(09). Available from: http://www.thieme-connect.de/DOI/DOI?10.1055/s-0028-1084041

61. Rasoanaivo P, Wright CW, Willcox ML, Gilbert B. Whole plant extracts versus single compounds for the treatment of malaria: synergy and positive interactions. Malaria Journal. $2011 ; 10(1): S 4$. 